\title{
HYDRAULIC EVALUATION OF SOME IRRIGATION DRIPPERS COMMONLY USED IN EGYPT
}

\author{
Abdelsalam H. S. ${ }^{1}$, El-Ansary M.Y., ${ }^{1}$,Awad, M.A. ${ }^{1}$, \\ Mostafa, H.M. ${ }^{1}$, and Sultan, W.M. ${ }^{2}$
}

\begin{abstract}
In Egypt, most of the newly reclaimed lands depend mainly on drip irrigation systems. The selection of good and appropriate drippers is the first step for successful drip irrigation system design. As well as, the uniformity of water application from drip irrigation system is affected by both water pressure distribution in the pipe network and hydraulic properties of drippers. Therefore, this study aimed to evaluate some irrigation drippers under different operating pressures and spacing on different lateral lengths widely used in Egyptian agriculture. The required hydraulic tests and measurements were conducted at National Irrigation Laboratory of Agricultural Engineering Research Institute (AEnRI), ARC, MOLAR, Egypt. These tests were carried out using 11 drippers of normal (non pressure compensated) and pressure compensated, on line and in line types of drippers with nominal discharges of 2, 4, and $8 \mathrm{~L} / \mathrm{h}$. All the drippers were tested and replicated thrice at operating pressure $(0.5$, $0.75,1$ and 1.25 bar), while all the drip irrigation lateral lines tests were at 100bar operating pressure for treatments of $0.25,0.50$ and $1.00 \mathrm{~m}$ dripper spacing on PE lateral lines of 25, 50 and $75 \mathrm{~m}$ lengths and 16 mm diameter.
\end{abstract}

Results indicated that, for the normal (Non-Pressure Compensated) drippers located at $1 \mathrm{~m}$ apart on lateral lines of 25, 50 and 75m lengths the emission uniformity (EU) values were 97.45, 96.87 and 85.4\%, respectively, when the drippers located on spacing of $0.5 \mathrm{~m}$ apart; the EU slightly reduced to $95.5,95.3$ and $81.5 \%$, respectively, while, for drippers spaced at $0.25 \mathrm{~m}$ apart, EU significantly reduced to 90.4, 84.6 and $77.2 \%$ respectively.

\footnotetext{
${ }^{1}$ Post graduate student, Prof. Emeritus and Associate Prof. of Ag. Eng., Fac. of Agric., Benha Univ.

${ }^{2}$ Senior Researcher of Agric. Eng. Res. Institute (AEnRI), ARC, MOLAR, Egypt.
} 
For pressure compensated (PC) drippers located at spacing of $1 \mathrm{~m}$ apart on 25, 50 and $75 \mathrm{~m}$ lateral lengths, the emission uniformity (EU) were 97.7, 94.8 and 86.4\%, respectively. At drippers spacing of $0.5 \mathrm{~m}$ apart; the emission uniformity $(E U)$ were 95.6, 92 and $83.8 \%$, while at dripper spacing 0.25m apart, the emission uniformity (EU) were $94.4,90.3$ and $82.6 \%$, respectively. So, emission uniformities of PC drippers were higher than that of normal NPC drippers especially at narrow dripper spacing and/ or long lateral lines.

For friction losses in the $16 \mathrm{~mm}$ diameter PE lateral lines of 25, 50 and $75 \mathrm{~m}$ lengths with $4 \mathrm{~L} / \mathrm{h}$ drippers located at spacing of $1 \mathrm{~m}$ apart, the actual measured friction losses were very close to the values created from theoretical calculation by Hazen -Williams equation using $C=140$.

Keywords: Drip irrigation, Emission Uniformity, Friction Losses, Laterals.

\section{INTRODUCTION}

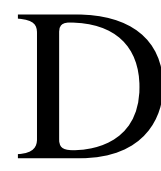
rip irrigation systems are in extensive use in Egyptian new lands due to its high control of the applied water. During recent years, numerous drip irrigation drippers with varying characteristics have become available in the Egyptian market. Through a properly designed drip system, a uniformity co-efficient of at least $85 \%$ is considered appropriate for standard design requirements. Such a high uniformity coefficient is only possible through properly designed drippers that provide steady discharge to all emission points, (AlAmound, 1995). Qualitative classification standards for the production of drippers, according to the manufacturer's coefficient of dripper variation $(\mathrm{CVm})$, have been developed by ASAE. CVm values below $10 \%$ are suitable and $>20 \%$ are unacceptable (ASAE, 2005). The dripper discharge variation rate (qvar) should be evaluated as a design criterion in drip irrigation systems; qvar $<10 \%$ may be regarded as good and qvar $>20 \%$ as unacceptable (Camp et al., 1997). Barragan and Wu (2005) stated that the total friction pressure loss could be considered as the allowed friction pressure loss to meet the set design criterion. A smaller value for the design coefficient means a less allowable friction drop that requires a design with a larger sub-main size and a shorter length of 
lateral line and a higher cost of the micro-irrigation system in the field. An ideal hydraulic design is to obtain the minimum pressure variation or a range of pressure variations close to the minimum for a given total friction pressure. The Objective of this work was to study the effect of some engineering factors (operating pressure, distance between dripper and lateral line length) on drip irrigation performance to assess the hydraulic performance of various kinds of drippers widely used in Egypt. Mizyed and Kruse (2008) reported that manufacturing variations, pressure differences, dripper plugging, aging, frictional head losses, irrigation water temperature changes, and dripper sensitivity result in flow rate variations even between two identical drippers. Also, the dripper operating characteristics tend to fluctuate over passing time. Thus flow might change even with a constant pressure. In fact using the manufacturer's data will lead to non-uniformity of discharge throughout the system (Singh et al., 2009).The performance of drip irrigation system is based on the proper design of drippers, spacing of drippers and proper spacing between delivery lines etc. But the design of drippers plays a prime role in uniform distribution of water on the field. To have the best emission uniformity and minimum flow rate fluctuation due to pressure distribution, some of the drippers have been designed as pressure compensating dripper. Some of them are self-cleaning or 'flushing' to reduce the clogging but others can be clogged easily and require sophisticated water filtration (Amir, 2012). The uniformity of water application from drip irrigation drippers depends on lateral lines length, drippers design, operating pressure, friction losses, the manufacturing variation of drippers and dripper's tendency to clogging. The uniformity of water is related to the pressure variation along the lateral line. The friction losses and the lateral line inclination largely affect the pressure variation (Sinobas and Rodríguez, 2012). The hydraulic analysis in order to obtain the discharge in any kind of dripper is another concern in drip irrigation design. Resolution of this problem is important to determine the efficiency of the system, which is called Emission Uniformity (EU). Different methods are discussed to calculate the dripper discharge throughout the system and each one has its own advantages and disadvantages (Rodríguez, 2012). 


\section{MATERIALS AND METHODS}

This research was conducted at National Irrigation Laboratory of Agricultural Engineering Research Institute (AEnRI), Dokki, Giza. The objectives of this study were to collect discharge rates at 4 different pressure levels of $0.5,0.75,1$, and 1.25 bar to assess the hydraulic performances of 11 types of drippers (these drippers were available on the Egyptian market and its characteristics are presented in Table (1)). The evaluation parameters were to calculate the Coefficient of manufacturing variation, dripper discharge coefficient and discharge exponent, in order to establish the dripper's flow rate sensitivity to pressure and comparing the results to the manufactures' specifications.

The drip irrigation systems test facility (Fig. 1) was used to evaluate hydraulic characteristics of drippers.

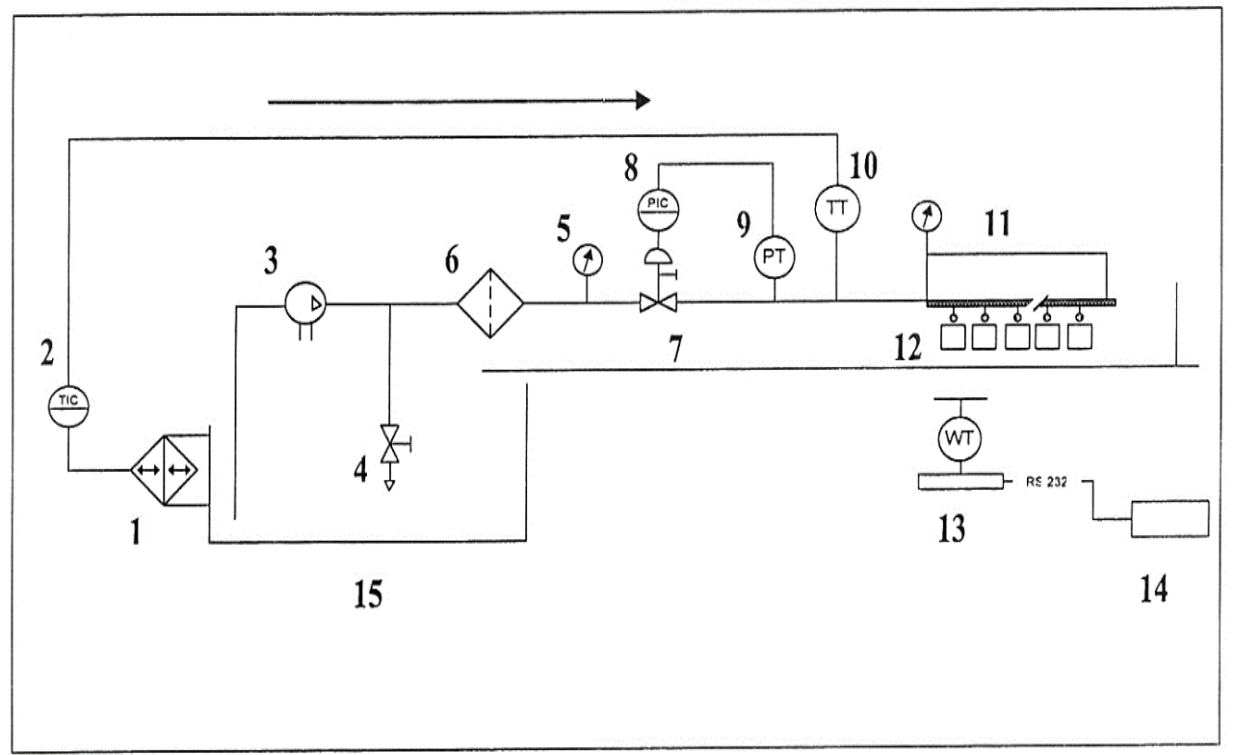

Fig. (1): Drip irrigation test facility.

1-Temperature conditioning; 2-Temperature regulator; 3-Multi stage pumping unit;

4-Manual discharge valve; 5-Direct reading pressure gauge; 6-Screen filter;

7-Pressurized air regulating valve; 8-Pressure regulator; 9- Pressure transmitter;

10- Temperature transmitter; 11- Lines of pipes including tested drippers;

12- Water collectors for each dripper in test; 13-Weighing scale;

14- Personal computer; and

15- Water tank. 
Poly Ethylene laterals (LDPE) of $16 \mathrm{~mm}$ outer diameter, $1.3 \mathrm{~mm}$ thickness, $3 \mathrm{~m}$ length, and $0.5 \mathrm{~m}$ dripper spacing were alternatively laid on zero-slope soil surface and tested in laboratory. For lateral evaluation, (4L/h) flow rate NPC and PC drippers spaced 1, 0.5 and $0.25 \mathrm{~m}$ apart on laterals with lengths of 75,50 and $25 \mathrm{~m}$ ) were tested at pressure of 1 bar. The drop pressure test facility (fig.2) was used to measure friction losses.

The system was operated for a period of 15 min for each data reading, replicating thrice for each of the selected drippers. Measurements were done according to ISO 9621 and ASAE stander (1996) for evaluating drippers' performance.

Before starting the experiments, air in the lateral was flushed out by opening its downstream end. The flow rates were taken and measured by weighting the water collected in plastic cylinders in a time of 3 minutes according to ISO 9621, as indicated by stop watch, to minimize error associated with the starting and stopping of the individual runs and residual water in containers, and multiply the weighting $(\mathrm{g} / \mathrm{min})$ on 0.02 in order to turn the weight to size $(\mathrm{L} / \mathrm{h})$ to calculate and evaluate the dripper performance.

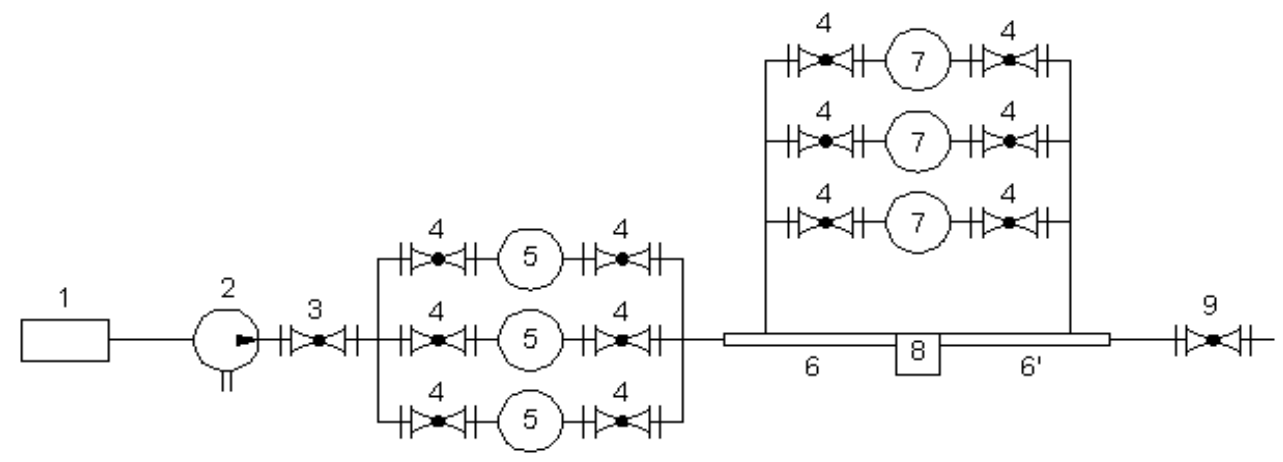

Fig (2) General sketch showing pressure drop test facility.

1. Water source

3. Discharge valve

5. Electromagnetic flow meters

7. Differential pressure gauges

9. General ball valve.
2. Pump

4. Manual isolating valves

6 and 6'. Set of straight pipes

8. Device to be tested and 
Table (1): Drippers type and its classification:

\begin{tabular}{|c|c|c|c|c|}
\hline No & Dripper type & $\begin{array}{c}\text { Flow rate } \\
\text { (L/h) }\end{array}$ & Classification & Dripper's Picture \\
\hline 1 & OT 1 & 2 & (NPC) & \\
\hline 2 & OT 2 & 4 & (NPC) & \\
\hline 3 & OT 3 & 8 & (NPC) & \\
\hline 4 & Button SD & 4 & (NPC) & \\
\hline 5 & GR1 & 2 & (NPC) & \\
\hline 6 & GR 2 & 4 & (NPC) & \\
\hline 7 & GR 1 PC & 2 & (PC) & \\
\hline 8 & RAIN BIRD & 4 & $(\mathrm{PC})$ & \\
\hline 9 & NEIN EPC & 4 & $(\mathrm{PC})$ & \\
\hline 10 & EDEN & 5 & $(\mathrm{PC})$ & \\
\hline 11 & Supertif & 8 & $(\mathrm{PC})$ & \\
\hline
\end{tabular}

Flow rate characteristics and variations:

The dripper flow rates are usually characterized by the relationship between flow rates and pressure. The equation for dripper flow rates can be expressed as (Keller and Karmeli, 1974):

$$
q=k p^{x}
$$

Where,

$$
\mathrm{q}=\text { the dripper flow rates, }(\mathrm{L} / \mathrm{h}) \text {, }
$$


$\mathrm{k}=\mathrm{a}$ dimensionless constant of proportionality that characterizes each dripper,

$\mathrm{p}=$ Operating pressure, (bar), and

$\mathrm{x}=\mathrm{a}$ dimensionless dripper flow rate exponent that is characterizes by the flow regime.

The dripper flow variation qvar was expressed by Wu and Gitlin (1983) and $\mathrm{Wu} 1997$ to simply compute uniformity of the drip system as followed:

$$
\begin{aligned}
& \boldsymbol{q}_{\text {var }}=\left(\left(\boldsymbol{q}_{\max }-\boldsymbol{q}_{\min }\right) / \boldsymbol{q}_{\max }\right) \times \mathbf{1 0 0} \\
& \text { Where }: \\
& \text { qvar }=\text { is dripper flow variation }(\%) \\
& \text { qmax }=\text { is maximum dripper discharge }(\mathrm{L} / \mathrm{h}) \\
& \text { qmin }=\text { is minimum dripper discharge }(\mathrm{L} / \mathrm{h})
\end{aligned}
$$

\section{Dripper manufacture's coefficient of variations $(\mathrm{CV})$ :}

The manufacture's coefficient of variation "CV" was calculated by measuring the flow rates from a sample of the new drippers according to (ASAE 1996 Standard), as follows:

$$
C V=\left(s / q_{a}\right) \times 100
$$

Where,

$\mathrm{CV}=$ manufacturer's coefficient of dripper variation, (\%);

qa. $=$ Average flow rate, $(\mathrm{L} / \mathrm{h})$, and;

$\mathrm{s}=$ Standard deviation of dripper flow rates at a reference pressure head.

\section{Emission uniformity (EU):}

Another measure of dripper uniformity (EU) is typically used to evaluate manufacturing quality of drippers. The EU is the ratio between the average discharge in the quarter receiving less water and the average discharge at the system level. It is used to describe the predicted dripper flow variation along a lateral line and can be assumed as synonymous to that of distribution uniformity (DU).

The following formula was used to calculate Emission Uniformity (Ortiga et al., 2002).

$$
E \boldsymbol{U}=\left(\boldsymbol{q}_{n} / \boldsymbol{q}_{a}\right) \times \mathbf{1 0 0}
$$

Where, $\mathrm{EU}=$ the emission uniformity, $(\%)$; 
qn $=$ The average of the lowest $1 / 4$ of the dripper flow rate, $(\mathrm{L} / \mathrm{h})$, and; $\mathrm{qa}=$ The average of all dripper flow rate, $(\mathrm{L} / \mathrm{h})$.

\section{Friction losses formula (hf):-}

The Hazen -Williams's formula (Watters and Keller 1978)

\section{$\mathrm{H} f=\mathrm{K}(\mathrm{Q} / \mathrm{c}) \mathbf{1 . 8 5 2} \mathrm{L}$ f D $\mathbf{- 4 . 8 6 5 5}$}

Where, $\mathrm{H} \mathrm{f}=$ head loss due to friction, $\mathrm{m}$,

$\mathrm{K}=1.22 \times 1010$

$\mathrm{Q}=$ pipe line discharge

$\mathrm{C}=$ friction coefficient for continuous pipe section,

$\mathrm{D}=$ inside diameter, $\mathrm{mm}, \quad \mathrm{L}=$ pipe line length, $\mathrm{m}$, and

$\mathrm{f}=$ Reduction coefficient for multiple let out (Christiansen, 1942).

$$
f=(1 /(m+1))+(1 / 2 n)+\left((m+1) / 6 n^{2}\right)
$$

Where:

$\mathrm{m}=$ the velocity exponent, and $\mathrm{n}=$ the number of outlets on the lateral

\section{RESULTS AND DISCUSSION}

\section{Pressure-flow characteristics:}

The effect of pressure on the dripper discharge varied for each dripper type. Average flow rate as a function of operating pressure was determined for all dripper types as shown in Table .2 and Fig (3). . All correlation coefficient were above (0.9), except the pressure compensating types which they have lowest correlation coefficient $(0.258$ and 0.016) for Supertif and EDEN respectively .Almost all on line normal (NPC) drippers were fully turbulent flow characteristics. EDEN, Supertif and $\mathrm{GR}_{1} \mathrm{PC}$ were fully pressure compensating.

\section{Dripper manufacture's coefficient of variation $(\mathrm{CV})$ :}

The dripper discharge equation, and Manufacture's coefficient of variation "CV" for each dripper were determined and the results are presented in Table (2) and Fig (4). The manufacture coefficient of variation "CV" is a function of the dripper type and the quality control exercised during the manufacturing process. The manufacture's coefficient of variation "cv" of different dripper types was relatively insensitive to the operating pressure and its classification varied from poor to excellent. Values of "cv" for the 11 dripper types resulted between 0.88 to $14.9 \%$, depending on dripper's design, the material used, and the care with which the drippers were manufactured. 

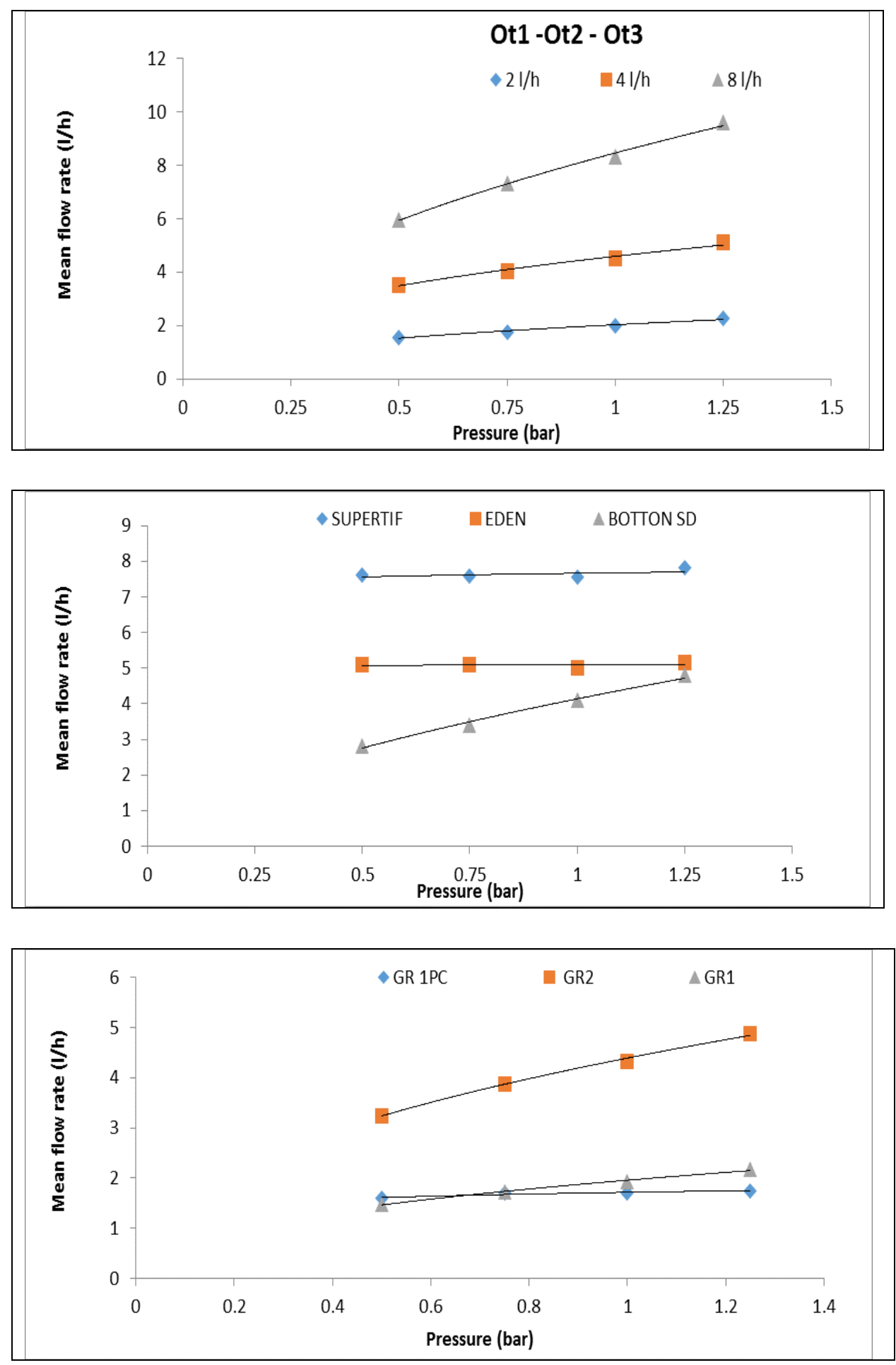

Fig 3: Performance curves of the acceptable tested dripper types. 


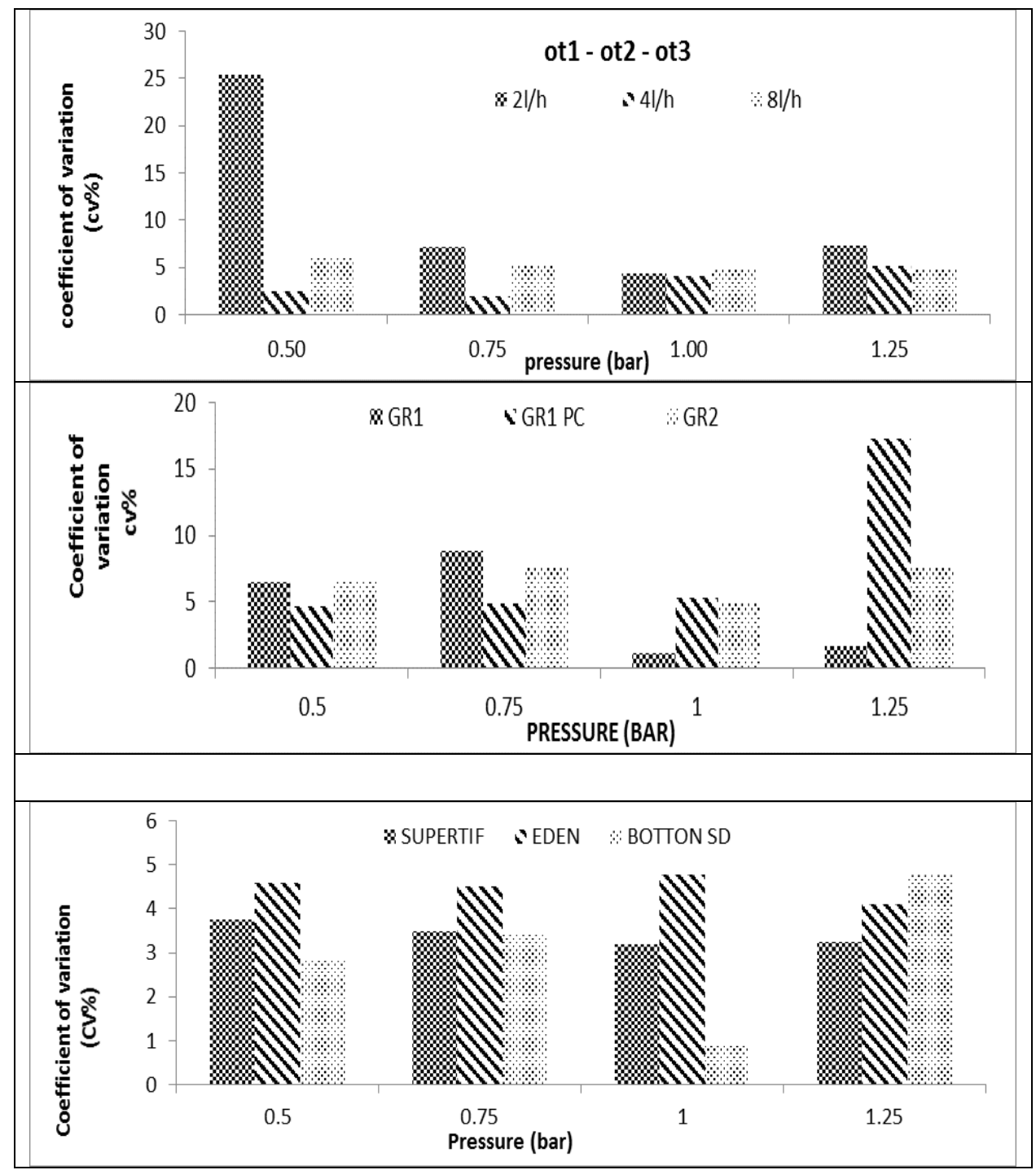

Fig 4: Manufacture coefficient of variation (CV \%), for the tested drippers under different operating pressure (bar).

\section{Emission uniformity (EU) and flow variation ( $q_{\mathrm{var}} \%$ ):-}

The Emission uniformity (EU) and flow variation $\left(\mathrm{q}_{\mathrm{var}} \%\right)$ for investigated types of drippers are presented in Table (3). EU values for the acceptable dripper types ranged from 91.8 to $98.8 \%$ which varied due to the variation of drippers manufacturing quality. Dripper flow variation $\left(\mathrm{q}_{\mathrm{var}} \%\right)$ was between 3.48 to19.6 (acceptable) Fig (4). 
Table (2): Manufacture's coefficient of variation (CV) \% at 1 bar for the 11 dripper types:

\begin{tabular}{|c|c|c|c|c|c|c|c|c|}
\hline \multirow[t]{2}{*}{ NO } & \multirow[t]{2}{*}{ Dripper type } & \multicolumn{2}{|c|}{ Flow rate, $(\mathrm{L} / \mathrm{h})$} & \multicolumn{2}{|c|}{$\begin{array}{c}\text { Manufacture's } \\
\text { coefficient of variation } \\
\text { (CV)\% at } 1 \text { bar }\end{array}$} & \multicolumn{2}{|c|}{ Parameters } & \multirow[t]{2}{*}{ Flow regime } \\
\hline & & $\begin{array}{c}\text { Nom } \\
\text { inal }\end{array}$ & Mean & $\mathrm{CV}$ & $\begin{array}{l}\text { ASAE } \\
\text { standard }\end{array}$ & $\begin{array}{l}\text { Dripper discharge } \\
\text { exponent }(\mathrm{X})\end{array}$ & $\begin{array}{c}\text { Flow coefficient } \\
(\mathrm{K})\end{array}$ & \\
\hline 1 & OT 1 & 2 & 2 & 4.2 & Excellent & 0.42 & 2.04 & Fully turbulent \\
\hline 2 & OT 2 & 4 & 4.5 & 4.007 & Excellent & 0.4 & 4.6 & Fully turbulent \\
\hline 3 & OT 3 & 8 & 8.3 & 4.3 & Excellent & 0.4 & 8.4 & Fully turbulent \\
\hline 4 & GR 1 PC & 2 & 1.75 & 4.8 & Excellent & 0.05 & 1.69 & $\begin{array}{l}\text { Fully pressure } \\
\text { compensating }\end{array}$ \\
\hline 5 & GR 2 & 4 & 4.3 & 4.7 & Excellent & 0.4 & 4.3 & Fully turbulent \\
\hline 6 & GR1 & 2 & 1.93 & 1.15 & Excellent & 0.4 & 1.9 & Fully turbulent \\
\hline 7 & RAIN BIRD & 4 & 3.78 & 13.85 & Poor & 0.22 & 3.87 & $\begin{array}{c}\text { pressure } \\
\text { compensating }\end{array}$ \\
\hline 8 & NEIN EPC & 4 & 3.8 & 14.9 & Poor & 0.274 & 4.17 & $\begin{array}{l}\text { Fully pressure } \\
\text { compensating }\end{array}$ \\
\hline 9 & EDEN & 5 & 5.09 & 4.77 & Excellent & 0.006 & 5.08 & $\begin{array}{l}\text { Fully pressure } \\
\text { compensating }\end{array}$ \\
\hline 10 & Button SD & 4 & 4.08 & 0.88 & Excellent & 0.49 & 4.08 & Fully turbulent \\
\hline 11 & Supertif & 8 & 7.57 & 3.4 & Excellent & 0.03 & 7.61 & $\begin{array}{l}\text { Fully pressure } \\
\text { compensating }\end{array}$ \\
\hline
\end{tabular}

Table (3) Emission uniformity (EU) \% and dripper flow variation (q var $\%)$ for drippers at 1 bar :

\begin{tabular}{|l|c|c|c|c|}
\hline \multirow{2}{*}{ Dripper type } & \multicolumn{2}{|c|}{ Emission uniformity (EU)\% } & \multicolumn{2}{c|}{ Dripper flow variation (qvar) $\%$} \\
\hline & Value & ASAE standard & Value & ASAE standard \\
\hline OT 1 & 95.75 & Excellent & 4.25 & Acceptable \\
\hline OT 2 & 95.5 & Excellent & 19.2 & Acceptable \\
\hline OT 3 & 94.4 & Excellent & 19.3 & Acceptable \\
\hline GR 1 PC & 92.9 & Excellent & 18.85 & Acceptable \\
\hline GR 2 & 92.5 & Excellent & 13.3 & Acceptable \\
\hline GR1 & 98.4 & Excellent & 7.6 & Acceptable \\
\hline EDEN PC NO- DRAIN & 91.8 & Excellent & 19.6 & Acceptable \\
\hline Button SD & 98.8 & Excellent & 3.48 & Acceptable \\
\hline supertif & 94.9 & Excellent & 12.14 & Acceptable \\
\hline
\end{tabular}


The effect of lateral length and spacing between drippers on emission uniformity and friction losses

\section{Non pressure compensating}

Data in Fig (5 and 6) showed that the effect of lateral length on dripper performance in using on-line drippers' lateral length 75, 50, and $25 \mathrm{~m}$ and dripper spacing $(0.25,0.5$, and $1 \mathrm{~m})$ according to ASAE, standard (1996). The values of that classified as fully turbulent flow. The values of emission uniformity were 85.4, 96.87, and 97.45\%with $1 \mathrm{~m}$ space between drippers. With changing the distance between drippers to $0.5 \mathrm{~m}$ the values of emission uniformity were decreased to $81.5,95.3$, and $95.5 \%$, also the EU values were decreased to $77.2,84.6$ and $90.4 \%$ with decreasing the dripper spacing to $0.25 \mathrm{~m}$. The decreasing in EU values with decreasing the drippers spacing duo to the increase in drippers number at the same lateral length which affecting the dripper discharge and flow resistance due to friction.

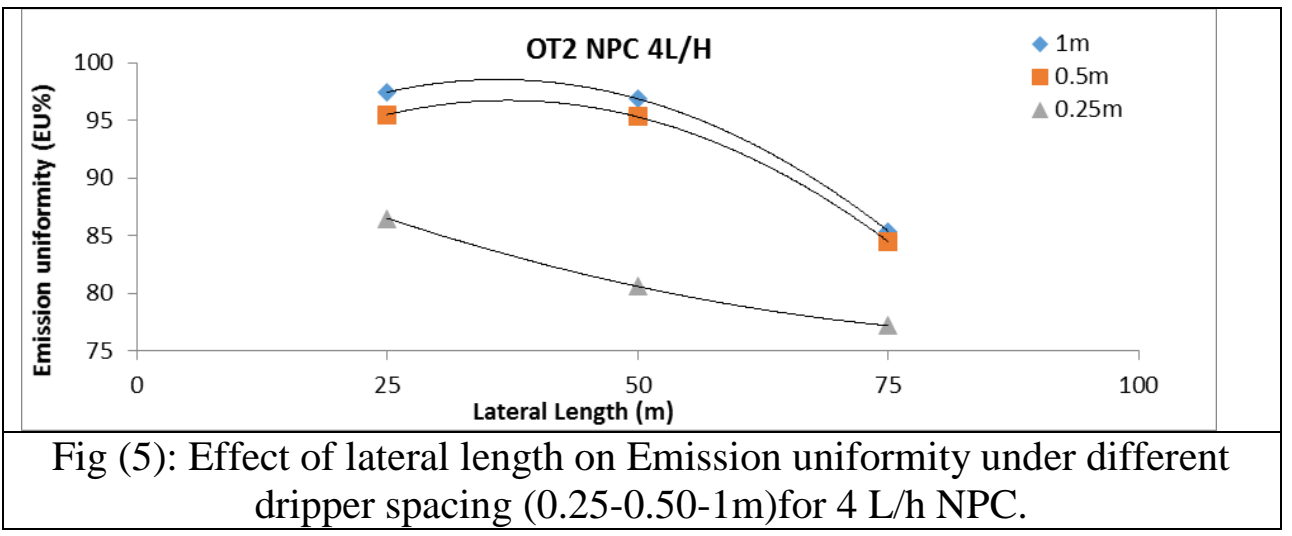

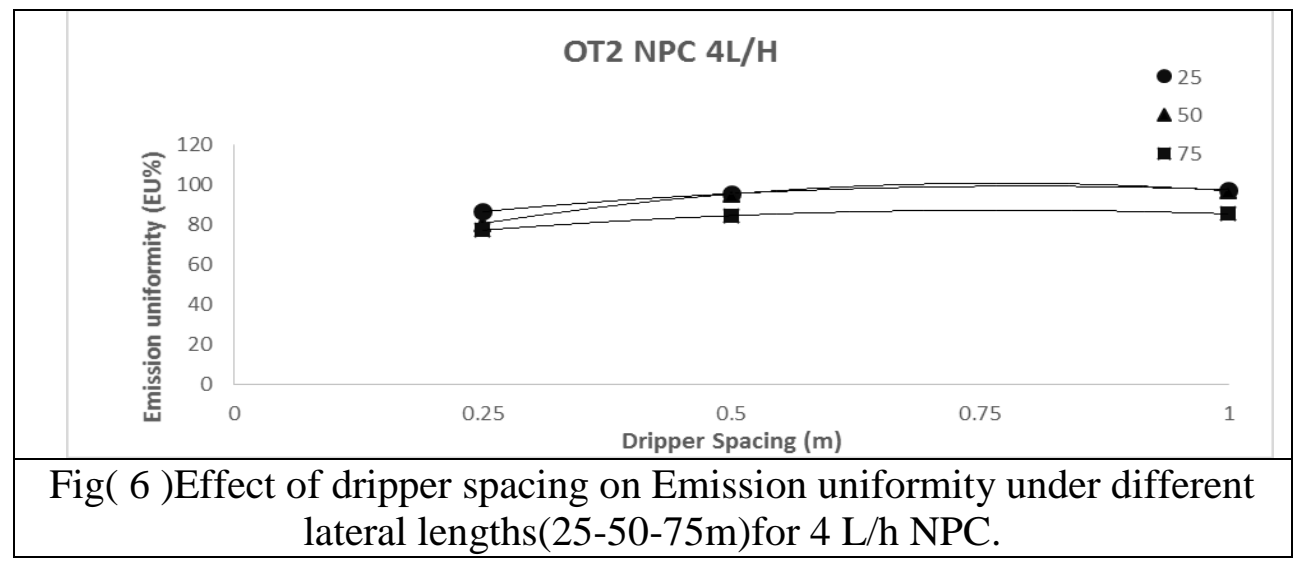




\section{Pressure compensating drippers.}

Data presented in fig (7and 8) showed the effect of lateral length on emission uniformity at lengths $(75,50$, and $25 \mathrm{~m})$ and dripper spacing $(0.25,0.5$, and $1 \mathrm{~m})$ for pressure compensating dripper.

At $1 \mathrm{~m}$ dripper spacing, the values of emission uniformity were $86.4,94.8$ and $97.7 \%$ respectively, while at $0.5 \mathrm{~m}$ the values of EU were 83.8, 92 and $95.6 \%$ respectively and at $0.25 \mathrm{~m}$, they were $82.6,90.3$ and $94.4 \%$

\section{respectively.}

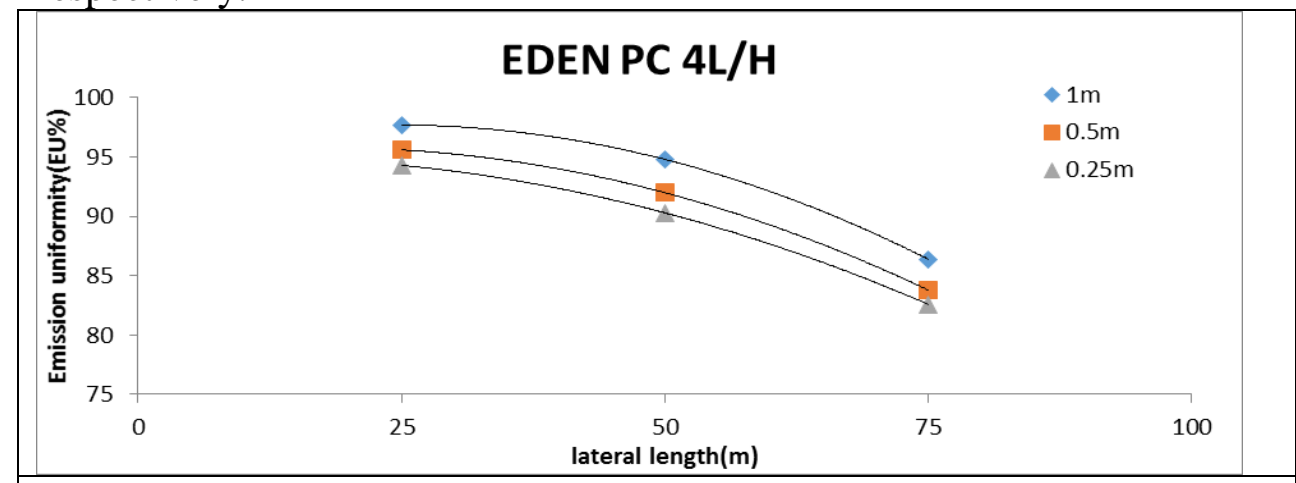

Fig (7) Effect of lateral length on Emission uniformity under different dripper spacing $(0.25-0.50-1 \mathrm{~m})$ for4 $\mathrm{L} / \mathrm{h} \mathrm{PC}$.

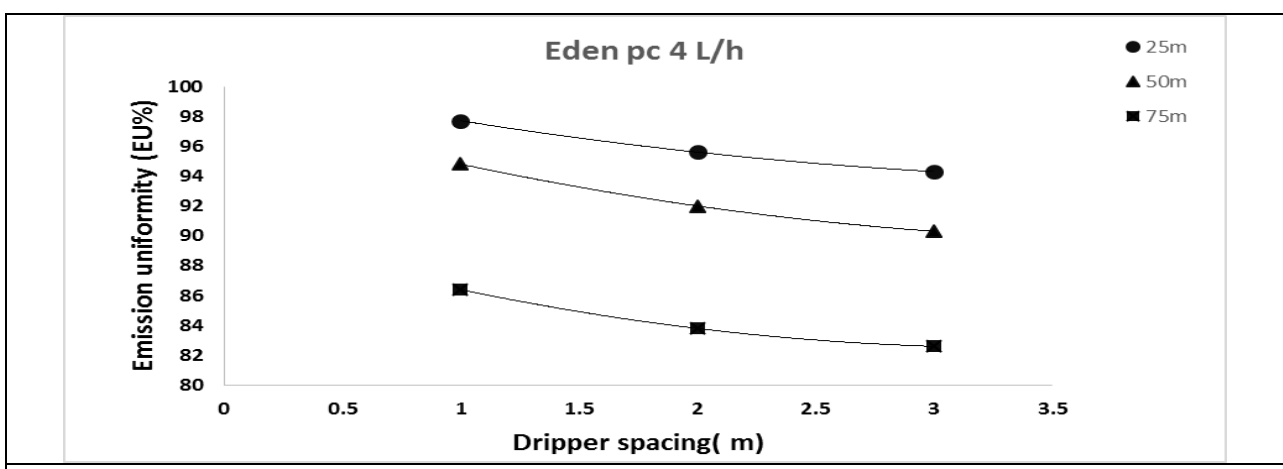

Fig (8): Effect of dripper spacing on Emission uniformity under different lateral lengths (25- 50- 75m)for $4 \mathrm{~L} / \mathrm{h}$ PC.

From the previous discussion, it can be noticed that the PC (pressure compensating) drippers which have the following specification, $q=4 \mathrm{~L} / \mathrm{h}$, with spacing $(1,0.5$, and $0.25 \mathrm{~m})$ will be the acceptable one in lateral lengths $(50$ and $25 \mathrm{~m})$ compare with $75 \mathrm{~m}$ because it was acceptable in all 
evaluating parameters. Lateral length 50 and $25 \mathrm{~m}$ have the highest uniformity.

\section{Theoretical and actual friction losses:}

Data in table (4) presented the theoretical and actual friction losses results for the flow rates $4 \mathrm{~L} / \mathrm{h}$ drippers affected by lateral length. The data showed that for all calculations the actual measuring of the friction loss were 2, 4 and $7.2 \mathrm{~m}$ for the lateral length 25,50 and $75 \mathrm{~m}$ respectively, when the spacing between dripper $1 \mathrm{~m}$. Also these data were closed to application of hazen - Williams's equation and take the same trend which were $2.17,4.29$ and $7.43 \mathrm{~m}$ respectively. But with spacing $0.5 \mathrm{~m}$, actual measuring of the friction loss were $2.3,5$ and $6.5 \mathrm{~m}$ for the lateral length 25,50 and $75 \mathrm{~m}$ respectively , and the theoretical calculation were 2.19, 4.33 , and $7.46 \mathrm{~m}$ for the same lengths respectively. When spacing between dripper changed to $0.25 \mathrm{~m}$, the actual measuring were $2.5,6$, and $10 \mathrm{~m}$ for lateral length 25,50 and $75 \mathrm{~m}$, and the theoretical were $2.21,4.39$,and $7.26 \mathrm{~m}$ respectively .

Table (4): Theoretical and actual Friction losses $\left(\mathrm{h}_{\mathrm{f}}\right)$

\begin{tabular}{|c|c|l|l|l|l|l|}
\hline $\begin{array}{l}\text { Lateral } \\
\text { length } \\
(\mathbf{m})\end{array}$ & \multicolumn{2}{|l|}{ Dripper spacing 1 m } & \multicolumn{2}{l|}{ Dripper spacing 0.5 m } & \multicolumn{2}{l|}{ Dripper spacing 0.25 m } \\
\hline & $\begin{array}{l}\text { Actual } \\
\text { Friction } \\
\text { losses } \\
(\mathbf{m})\end{array}$ & $\begin{array}{l}\text { Theoretical } \\
\text { Friction } \\
\text { losses (m) } \\
\text { Hazen } \\
\text { Williams } \\
\text { (C=140) }\end{array}$ & $\begin{array}{l}\text { Actual } \\
\text { Friction } \\
\text { losses } \\
(\mathbf{m})\end{array}$ & $\begin{array}{l}\text { Theoretical } \\
\text { Friction } \\
\text { losses (m) } \\
\text { Hazen } \\
\text { Williams } \\
\text { (C=140) }\end{array}$ & $\begin{array}{l}\text { Actual } \\
\text { Friction } \\
\text { losses } \\
(\mathbf{m})\end{array}$ & $\begin{array}{l}\text { Theoretical } \\
\text { Friction } \\
\text { losses (m) } \\
\text { Hazen - } \\
\text { Williams } \\
\text { (C=140) }\end{array}$ \\
\hline 75 & 7.2 & 7.43 & 6.5 & 7.46 & 10 & 7.62 \\
\hline 50 & 4 & 4.29 & 5 & 4.33 & 6 & 4.39 \\
\hline 25 & 2 & 2.17 & 2.3 & 2.19 & 2.5 & 2.21 \\
\hline
\end{tabular}


From the previous data it may be concluded that:-

- No significant difference between the actual and theoretical friction losses calculations according to Hazen -Williams's equation. This may be due to the relatively short lateral lines.

- As laterals line length increased, or/and dripper spacing on the lateral line decreased, the friction losses per meters will be increased.

\section{CONCLUSION}

The manufacturing variation of emission devices has a significant effect on drip irrigation system water uniformity. The uniformity decreased by increasing the coefficient of manufacturing variation.

Uniformity coefficient is an important design and scheduling parameter.

Lateral line length was the major effective on drip irrigation line application .As lateral lines increase drip irrigation system decreasing in (EU, CV, and the type of flow).This may be due to the increasing of friction loss along the lateral line.

The lateral length of $25 \mathrm{~m}$ and $50 \mathrm{~m}$ were better than $75 \mathrm{~m}$.

Recommendation from this search:

When using on line drippers with flow rate $(4 \mathrm{~L} / \mathrm{h})$ at spacing $0.5 \mathrm{~m}$, the lateral length must be less than $75 \mathrm{~m}$ but at spacing $0.25 \mathrm{~m}$ lateral length must be less than $50 \mathrm{~m}$,that suitable for $16 \mathrm{~mm}$ tube .

\section{REFERENCES}

Al-Amound, A. I. 1995.Significance of energy losses due to dripper connections in trickle irrigation lines. J. Agri. Eng. Res., 60: 1-5.

Amir, K. (2012). Optimum Design of Drip Irrigation System using Microtubes as Drippers. M.Sc., School of Civil, Environmental and Chemical Engineering, College of Science, Engineering and Health, RMIT University,Australia.s 
ASAE STANDARDS,. 1996.. Field evaluation of micro-irrigation systems. St. Joseph, Mich. EP458 ASAE: 43rd ed 756-761.

ASAE STANDARDS. 2005.. Design and Installation of micro- irrigation systems. ASAE, St. Joseph, Mich. EP405.1 FEB03

Barragan J; Wu I P (2005). Simple pressure parameters for microirrigation design. Bio-systems Engineering, 90(4),4634doi:10.1016/j.biosystemseng.2004.11.009.

Camp, C.R., E.J. Sadler and W.J. Busscher. 1997. A comparison of uniformity measure for drip irrigation systems. Transactions of the ASAE, 40: 1013-1020.

Christiansen J.E., (1942). Irrigation by sprinkling. Ca. Agric. Exp. St. Bull No. 670. U. of Cal., Davis, Ca.

Keller J. and D. Karmeli, (1974). Trickle irrigation design parameters. Trans. of the ASAE, 17(4): 678-684.

Mizyed, N. and E. G. Kruse. 2008. Dripper discharge variability of subsurface drip irrigation in uniform soils: Effect on water application uniformity. Transaction of the ASAE, 26: 451-458.

Singh, A. K., Rahman, A., Sharma, S. P., Upadhyaya, A. andSikka, A. K. 2009. Small holders' irrigation - Problems and options. Water Resources Management, 23, 289-302.

Sinobas L. R., and M. G. Rodríguez (2012). A Review of subsurface drip irrigation and its management, Water Quality, Soil and Managing Irrigation of Crops, Dr. TeangShui Lee (Ed.), ISBN: 978-953- 510426-1.

Tagar A. A., M. S. Mirjat, A. Soomro and A. Sarki, (2010). Hydraulic performance of different drippers under varying lateral lengths. Pak. J. Agri., Agri. Eng., Vet. Sci., 26 (2): 48-59.

Watters, G.Z., and J. Keller, (1978). Trickle irrigation tubing hydraulics. Trans. of ASAE, Pp. No. 78, 2015 ASAE, St. Joseph, Mich 49085. 
Wu, I. P. and H. M. Gitlin, (1983). Drip irrigation application efficiency and schedules, Trans. ASAE,28: 92-99.

Wu I.P. (1997). An assessment of hydraulic design of micro-irrigation systems. Journal of Agricultural Water Management, 32(3): 275284.

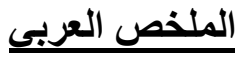

تقييم هيدروليكى لبعض نقاطات الرى شائعة الإستخدام فى مصر

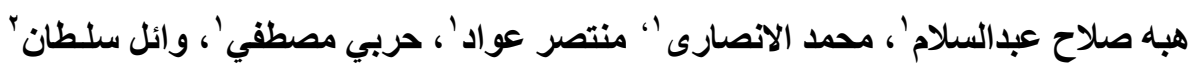

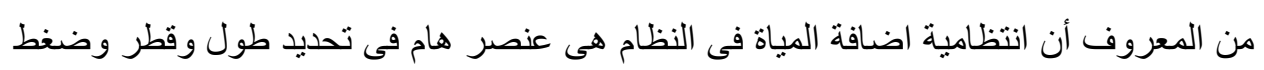

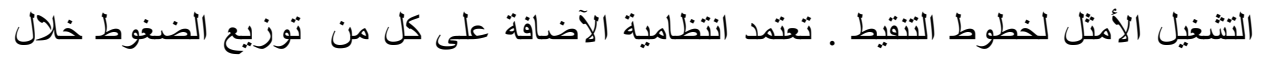

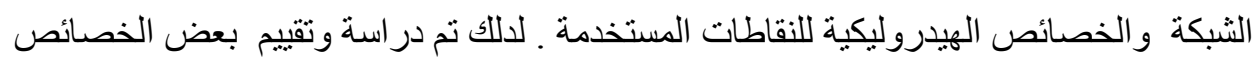
الهيدروليكية لأحدى عشر نوعا مختلفا من النقاطات المحلية والمستوردة الثائعة الاستخدام

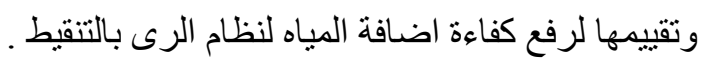

وقد أجريت التجارب المعطية في المعل القومي لإختبارمكونات شبكات الري الحقلي بمعهد

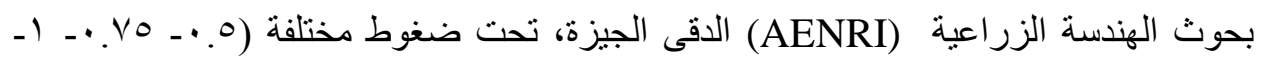

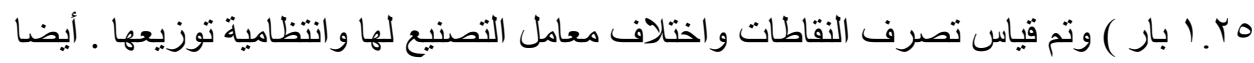

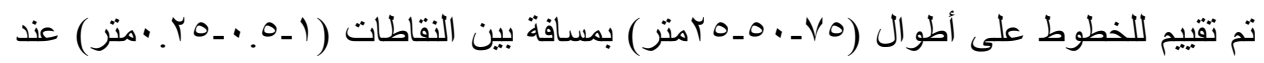

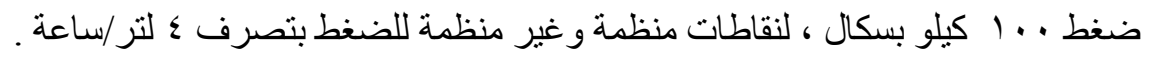

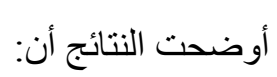

تسعة نقاطات( ب محلية الصنع ، 7 مستور دة ) كانت ممتازة الأداء ، و ب نقاط مستورد

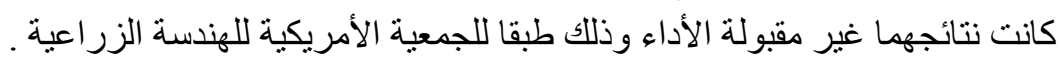

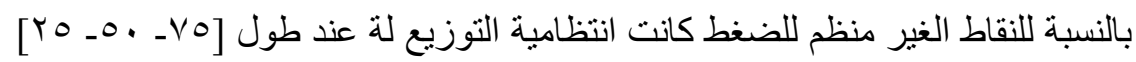

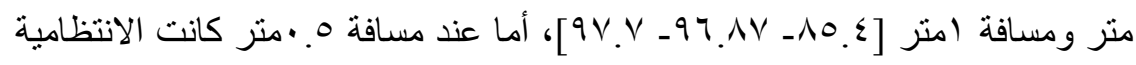

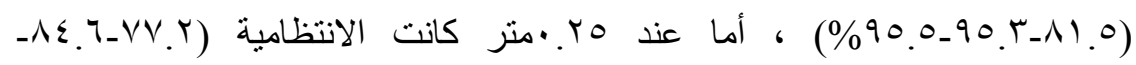
ـ ـ . 9\%) النفس الأطوال على الترتيب.

' طالبة دراسات عليا_ أستاذ متفرغ ـأستاذ مساعد ـ هندسة النظم الزراعية والحيوية كلية

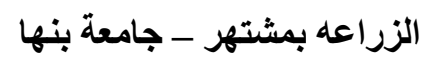

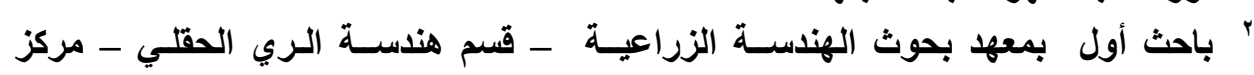
البحوث الزراعية. 


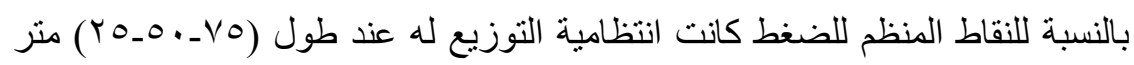

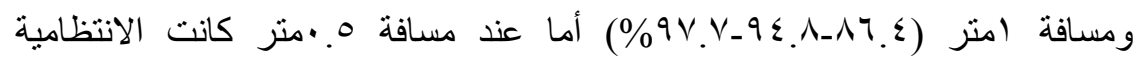

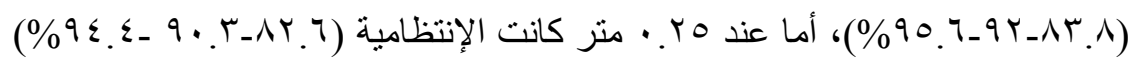
لنفس الأطو ال على الترتيب.

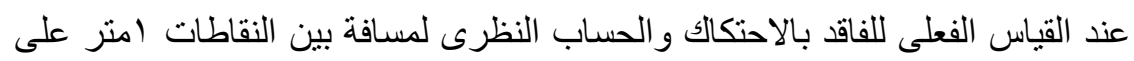

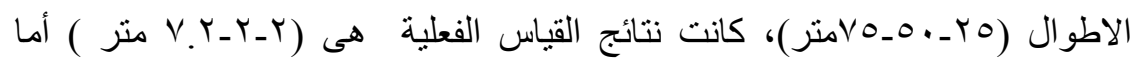

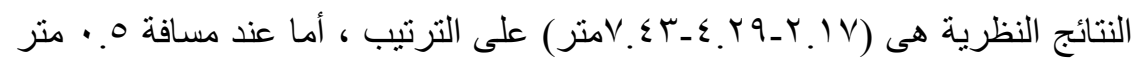

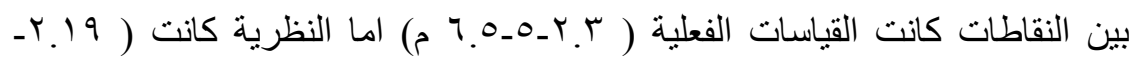

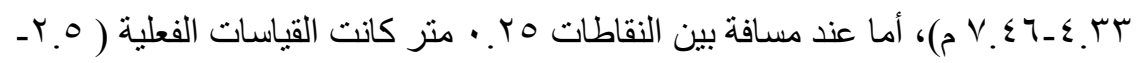

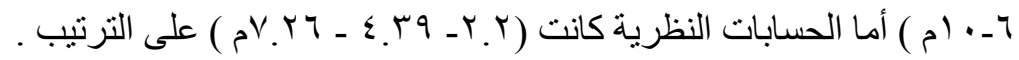
الخلاصة:

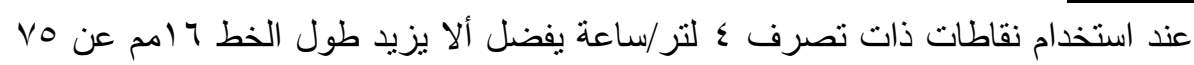

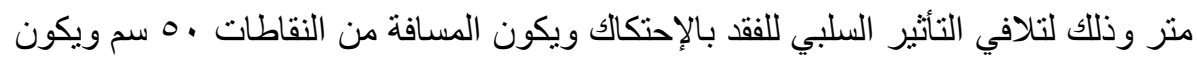

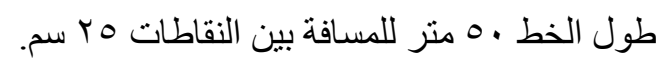

